\title{
Diachronic study of Uzbek and English architectural construction terms.
}

\author{
Nargiza Saloydinova, Tashkent institute of architecture and civil engineering Republic of Uzbekistan \\ Oybek Ahmedov, Tashkent institute of architecture and civil engineering Republic of Uzbekistan \\ Hilola Zakirova , Tashkent institute of architecture and civil engineering Republic of Uzbekistan
}

\begin{abstract}
New technologies demand on educational institutions call for innovative methods of language and content instruction. The aim of the paper is to present terminology and research in the field of architecture and construction. The crucial issues concerning unification, normalization, creation of terminological dictionaries which could satisfy completely the needs of experts working in various areas of science or architecture and construction are very important. The development of ways of term formation and terminology contributes to the active participation of experts in solving actual issues of modern science and technology, thereby increasing their informational awareness. The goal was to analyze terminology in architecture and construction.
\end{abstract}

Keywords: architecture, construction, terminology, term, arches, consoles, pilasters, concrete cells. Received: 14.12.2020 Accepted: 25.01.2021 $\quad$ Published: 07.02.2021

\section{Introduction}

The formation of the terminological system of each industry, depends on the field and develops in close connection with each other. Therefore, the architecture-construction terminology is composed, formed and developed on the basis of genetic basis.

With the formation of construction in the state, the state began to pay attention to the reconstruction and beautification of cities and began to build buildings in order to create comfort for living conditions. Because the development of any state depended primarily on the appearance of the state, the construction infrastructure, the reconstruction of cultural and ancient, unique buildings in the city. Architecture-construction is one of the main factors that ensure the economic prestige, cultural development and state of international relations of each state and determine the socio-economic development of society. Therefore, it is important to conduct scientific research through linguistic terms, studying the history of the formation and composition of the architectural and construction industry, their content, types, terms used in the past on the basis of scientific sources. Views on the types, forms, systems, socio-economic significance of construction in the Central Asian region go back to ancient times in the history of countries such as ancient Egypt, Rome, China, India. If we look at the history of statehood, it is clear that the history of the formation of architecture-construction terminology is also related to the state of man and his activities.

The main goal of the article is to reveal and to describe the formation of the terminological system of each industry, depends on the field and develops in close connection with each other. Therefore, the architecture-construction terminology of Uzbek language is composed, formed and developed on the basis of genetic basis.

With the formation of construction in the state, the state began to pay attention to the reconstruction and beautification of cities and began to build buildings in order to create comfort for living conditions. Because the development of any state depended primarily on the appearance of the state, the construction infrastructure, the reconstruction of cultural and ancient, unique buildings in the city. Architecture-construction is one of the main factors that ensure the economic prestige, cultural development and state of international relations of each state and determine the socio-economic development of society. Therefore, it is important to conduct scientific research through linguistic terms, studying the history of the formation and composition of the architectural and construction industry, their content, types, terms used in the past on the basis of scientific sources. Views on the types, forms, systems, socio-economic significance of construction in the Central Asian region go back to ancient times in the history of countries such as ancient Egypt, Rome, China, India. If we look at the history of statehood, it is clear that the history of the formation of architecture-construction terminology is also related to the state of man and his activities.

Historical sources testify that the emergence of a particular concept of architecture- construction dates back several centuries BC. For example, it is well known from world history that 4,500 years ago in Egypt, 
one of the seven wonders, the "Pyramid of Cheops" or the "Pyramid of Giza" was built. At that time, the first small construction structures appeared in the tribes in what is now Central Asia. [Arnold, Dieter (2005). p- 97.].

Mankind's architectural and construction activities date back to the Paleolithic period, and it depends on humanity building houses for themselves using the simplest stone tools. In the Paleolithic period, the field of architecture served not only as a field of technical activity, but also to meet the spiritual needs of mankind. During this period, terms related to the word stone begin to enter. In the wood-rich areas, houses were built of wood. After the Paleolithic period, the construction of houses began in the Neolithic period. During this period, the appearance of megalithic structures began. Megalithic devices are mainly divided into three types: mengirs, dolmens and cromlexes. Examples of structures found in ancient Egypt are mastabas, mausoleums, and pyramids. Protodor pillars were built at the entrance to the pyramids. In ancient Mesopotamia, the construction of high ziggurats, which served as a defense, led to the construction of arched and domed buildings. Arched and domed structures were among the first in the history of architecture in the world to be built during the Sassanid period. The largest building in the Achaemenid period was the royal palace in Persipol. The main part of the palace consists of a multicolumned hall - "apadana".

Ancient Greece was the birthplace of the sciences of geometry, mechanics, statistics, and on the basis of these sciences the field of civil engineering is developing. Achievements in civil engineering include the construction of cities, bridges, dams.

In the field of architecture, however, Roman architecture is of particular interest, as architectural terms are mainly named after the structure of the building material, mainly due to the widespread use of baked brick and natural stone blocks. The preparation and use of concrete became widespread in Roman architecture, after which terms related to the word concrete began to appear. If we look at history, we will find evidence that each state has created a new building, style in each century, with its own unique architecture and construction. It is from the process of construction of these structures that new terms began to appear in dictionaries by mankind.

There is a specific subject and object of knowledge in the field of architecture and construction. The design and construction of buildings and structures is studied as the art of creating an environment of material organization. At the same time, other disciplines are involved in the study of architecture, such as philosophy, architectural history, sociology and geography.

The basis of architecture is the emergence, development and functioning of architecture as an art, its essence and content, and the general laws of form. The subject of study of architecture consists of basic systems. These include sub fields which contain their terms according to the role using this sub field were given by the great architect Vitruviy:

1. Determining the vector of development of architecture

2. Description and substantiation of stylistic trends

3. Patterns of the emergence of architectural styles

4. Theory and history of architecture

5.Study the artistic language and artistic images of semantics-architecture.

6. Semiotics is the science of signs.

7. Syntactic codes - a characteristic feature in this sense is the code belonging to the construction technique.

8. Architectural form-beams, ceilings, arches, consoles, pilasters, concrete cells.

The science of architecture studies the elements that represent the basic functions, the elements that represent the secondary symbolic symbols, the elements that represent the ideology of life. Each of these elements has terms that have meaning. Architectural terms refer to designers, architects, decorations, styles, city names.

\section{Results and discussion}

According to the result of comparative-typological analysis the most important topic of this research helps to know the category of terms, in which groups they are used, on what principles they are based. A comparative morphological analysis is needed to find out what "unity of truth" is used in the unit, that is, where it is used in this process.

It should be noted that the units of speech were not considered in the usual way in our work, but on the basis of a new perfect coordinate system given by U.S. Kubryakova. According to E.S. Kubryakova, the term and the word, which clearly express the unity of speech, are based on its genesis, which originally appeared on the basis of naming fragments, named in accordance with the process in the world of speech of speakers. (Kubryakova 2004, 134). 
Determining the classes of words can be done in parallel by observing the different states of their different forms of matter, their changes. Moreover, the semantics of existing speech units have historical roots in their modern form, as the last layers shortened the initial roots of the words and removed them from the original root. Analysis of terms from a morphological point of view is an important process that can help us answer key questions about complex cognitive aspect research in the terminology system, helping us to determine exactly what speech unit represents in the language field in a scientific text. The meaning of the term (mental) in the lexical unit and in the verbal activity depends on its presentation and orientation in the speech unit.

The description of the scientific work is based on the following scheme: in the first stage the main terms are separated, in the second stage the selected terms are analyzed on the basis of languages.

In compiling the nominative concepts of architectural and construction terms, we did not limit ourselves to the correct names, we considered all the existing nominative fields, i.e. the names of their various denotations, so we analyzed the key terms, lexical units that describe the activities that take place in the architectural and construction process.

The central term in the field of architecture is the root of architecture, which is a representative term on the basis of. The terms are derived.

In the first stage, the core of the nominative field of a term is defined by words, consisting of its root. "Arch", "archivolt", architrave need to be found again.

One of the next steps is to determine the sign and function of the term based on the definition of the terms being analyzed. The term architecture means art, construction and design of buildings, the creation of exemplary artistic ensembles, the creation of an aesthetic attitude to the object of construction, the main purpose of architecture is to create an environment for work, living and recreation. (www.glossary.ru).

It is clear from the descriptions that the core of the term architecture is art, that is, in 1563 it was assumed that the French language came to European countries - architecte, Latin architectus or Greek. The exact source of the term has not been determined, as architecture entered European countries after the development of Egyptian and Greek architecture. For example, the term "architect" is said to have come into English from the Greek word "architect" meaning master builder, archi- + tektōn builder, carpenter-carpenter, or from Latin, as there is still no evidence that European architecture developed in the Middle Ages. In the early days, the work of architects in Greek and Egyptian architecture was among the leading professions. This is why the architecture of these terms came from developed countries. The word "architecture" came into Russian in 1705 from Polish.

The terms arch, arc, archivolt, architrave arcade, arkal, arkan are all derived from Latin and Greek.

As architecture developed, the term architecture led to the creation of term combinations by adding a few words to it. These include the following.

Architectural styles, landscape architecture, green architecture, hi-tech architecture, ancient architecture, modular arcitecture, new architecture,monument of landscape architecture, information systems architecture, contemporary architecture, classical architecture, open architecture, architectural structure.

The terms of architectural styles is related to Shelter, Pre-Columbian, Pre-Romanesque, Romanesque, Palladian.processes, country names to the architecture of the periods occupied by the explorers and tribes who discovered the periods, tribes, construction.

The architectural terms of the period include Early architecture, Medieval architecture, Renaissance architecture, Early modern and industrial architecture, Gothic, Baroque, Rococo,, Early civilizations, Neolithic styles. , Africa, Greek, Roman, Byzantine, Islamic, Persian, Indian, Eastern Asian, Georgian, German work federation".

Early modern and industrial architecture terms include Art Nouveau, Aesthetic movement, Arts and Craft Movement,

The terms "architectural views" are derived from the English word "irregularly shaped," meaning of this term is originally by French meant "durni". The word was later used in the 17th century to describe wonderfully curved lines, gold, and beautiful styles.

The term was later used to denote an ornamental or elaborate style. The style that Giorgio Vasari used in his Life of Artists as "barbarian German style" is now called "Gothic architecture". The Goths (from Greek, Romanized, Latin Gothi) are a Germanic people who played an important role in the collapse of the Western Roman Empire and the emergence of medieval Europe. They were written by Greek and Roman writers in the 3rd century BC. The peoples living north of the Danube in present-day Ukraine, Moldova, and Romania. The term "Rococo architecture" is a less common style of Baroque architecture that uses art, ornamentation, decorative theater, asymmetry, and curves, white and pastel colors. Rocaill was originally a style of decoration, often used as a sea shell and style to decorate stones and fountains since 
the Renaissance. In the late 17 th and early 18th centuries, ornaments intertwined with rocaille aquantus leaves, caused.

The development of science, culture, literature, painting in the Middle Ages and the Renaissance, the beautification of the architecture of buildings in European countries led to the emergence of new architectural terms. Architectural terms include works of art, beauty, unusual ornaments (French guirlande, Italian ghirlanda, Latin gerrae - woven), plants (acantus), names of creatures (gargales, garguli), denticles (Latin), leaves and food-like ornaments (ionics), (gol. crabbe).

After analyzing materials we can directly think that origin of English architectural terminology borrowed by Latin, Greek and French languages. Because, at that time, art was developing in the Middle century where the outstanding monuments, constructions, buildings were built in Greece and Egypt. According to this we came to this point that Latin and Greek languages were the global languages which influenced to the origin and formation of architectural terms. French was the key for formation of new architectural terms of new century by adding them some words.

But the research of H.Dadaboev was the important research for development of vocabulary. Almost all of his scholarly work is devoted to the study of terminological problems has been scientifically analyzed comprehensively in the example of language [ Pp. 73-240]. His above-mentioned scientific works not only provide rich factual-analytical material on the history of terms, but also give an idea of the own layer used in the system of military, socio-economic terminology, as well as the Arabic, Persian and Mongolian languages. In his works, the meaning of the terms used in the Orkhon-Yenisei inscriptions, ancient Turkic language monuments and old Uzbek language sources, their subtleties of meaning are often explained with the help of material evidence from the monuments.

Materials about the first architecture-construction systems and terms in the East can be found in the works of Chinese scientists [5]. They are in the ancient Turkic, Sogdian languages and were written by Buddhist and Moni communities.

According to some sources, the first appearance of the terms AC in the Uzbek language dates back to the VII-VIII centuries. Because the conquest of the territory of Movarounnahr by the Arab caliphate in the VIII century led to a radical change in the socio-economic system and attention to the architectural and construction system. Islam embraced all aspects of the life of the people of the region, internal and external relations, and led to the development of constructions in the internal structure of the city. The biggest change in architectural and construction activities after the Arab conquest was the construction of mosques, mausoleums and altars. This is because in Islam, prayer and fasting were considered "one of the five pillars of the religion" [223; 34-p.].

According to historical sources, the "mosque" was one of the main buildings that appeared in the early days of Islam. In Muslim countries (especially during the khanate period) "Prayers to the mosque were performed five times, and more attention was paid to the construction of the building to attract Muslims when they came to pray. [6.]. It was also mandatory for architects and builders in feudal Muslim states to have mathematics and art [195; 169-b.].

Sources say that over time, the term mosque has not changed its meaning. The term "mosque" appears 200 times in the holy book of Islam, the Qur'an.

In fact, the term mosque is a lexeme with a polysemantic character. 1. Masjid is a term used in Islamic architecture to mean "masjid" (plural - masadjid), which comes from the Arabic root s-dj-d - to fall to the ground - means "to bow down", "to bow to the ground" [ 7]. Religious practice means a place of obedience to Allah when praying. [Zhukovskiy, Koptseva, 2005, p. 348]

According to the collected scientific data, the etymology of the origin of the term mosque is directly related to the term Islamic architecture, one of the main religious practices built in the Arab-occupied territories is related to the concept formed for prayer.

After the end of Arab rule in Central Asia, the Samanid rule was established in the 10th century. During the Samanid period, the construction of mosques, minarets, pulpits and altars developed. [8].

Terms related to Islamic architecture is a composition of different architectural styles formed from Islam as a social, cultural, religious and political phenomenon, including the structure of religious and secular institutions and buildings, including Islamic architecture. Islamic architecture is reflected in both history and the architecture of modern buildings. In Islamic architecture, words from Mongolian, Arabic, Hindi, Turkish, and Iranian became terms. [9.].

Some of the terms of historical architecture and construction in the work of Mahmud Kashgari, the founder of Turkish lexicography, "Devonu lug'atit turk", rabot, ravoq, minbar, ordu (city where the king lives, orda), urumzun (paint, color), ubuzlug' (deep ground), opri (deep burial ground), ogulmuq (wooden column erected to put a beam on it), ochuqluk (kiln ground), ishlati (to use), irpadi (sawed), asriladi (painted), qat (storey), ev-bark (house and yard), tamur (iron) and other Turkish construction terms are widely used. 
The terms of the historical AC in the Uzbek language can also be found in the work of Zahiriddin Muhammad Bobur "Boburnoma". Note the following passage from the Boburnoma; : Буни Чилустун (қирк устунли) дейдилар, икки қаватли, устунларнинг хаммаси тошдан. Бу иморатнинг тўрт бурчагида минорасимон тўрт бурж ( ичи айлана зинали миноралар) тиклаганларки, юқори чиқиладиган йуллар бу буржлар орқалидир. Бошқа жойдаги хамма устунлар тошдан. Баъзисини тошни ёниб илон ўоалган тарзда ўймакорлик билан ишлаганлар. (Uzb) . It is called Chilustun (forty columns), two-storied, all the columns are made of stone. At the four corners of this building were erected four tower-shaped towers (inner circular staircase towers), the exits of which are through these towers. Elsewhere, all the columns are made of stone. Some were carved in the form of a stone burning snake (Eng).(Boburnoma) It can be seen from the content of the text quoted from "Boburnoma" that the role of the construction industry in the state was important. Because there were a lot of defensive buildings under construction. The following sentence also confirms our opinion: Улуғбек Мирзо мадрасаси томининг устида оқ чодир тикиб уттирдим. Бошқа беклар ва йигитларга дарвозаларда, қалъанинг айланаси буйлаб деворлар устида назорат масофалари тасдикланди. Икки-уч кундан сўнг Шайбоқхон келиб шахар кўрғонидан йироқроқ бир ерга тушди. (Uzb). I pitched a white tent on the roof of Ulugbek Mirzo Madrasah. Other beys and young men were confirmed control distances on the walls at the gates, around the perimeter of the castle. Two or three days later, Shaibakhan came and landed far away from the city fortress.(Eng) [ Boburnoma.].

It is understood that during the reign of the Baburi dynasty, some of the structures used in practice were used in conjunction with names, terms, nicknames and nicknames that make up the macro scale of anthroponyms. Note the following sentence: .... Биз- Боғу Чағониёнийлар ва баъзилар Қобул устига бормоққа қарор қилиб, у ердан куучиб келиб Або қорууғига (хукмдор оиласининг ёзги истирохат маскани) га тушдик (Uzb). We, the Garden Chaghanids, and some of us decided to go to Kabul, and from there we moved to the Abo fortress (the summer residence of the ruling family). (Eng) [ Boburnoma.].

Terms that have survived to the present day: Улуғбек Мирзонинг йирик иморатларидан Самарқанд қалъасининг ичидаги мадраса ва хонақохдир.Хонақохнинг гумбази жуда каттадир.Мадрасанинг жанубида Масжиди Муқатта (бўлакланган маъносини англатади, бўлак-бўлак ёғочлар тахлаб ислимий ва хитой нақшлари солинган. (Uzb).One of the largest buildings of Ulugbek Mirzo is the madrasa and the khanaqah inside the Samarkand fortress. The dome of the khanaqah is very large.(Eng.)[10]

\section{Conclusion}

One of the main features of AC terminology is that it has a structural character. The terms of the field are in an interconnected circle in a lexical-semantic situation in the structure of this system.

As observed in all areas, the unification of terms in translation, bringing the terms into a single form of expression in the areas of $\mathrm{AC}$ is very relevant. The AC terms, which form the semantic basis of texts related to the field, serve to develop payment obligations in a clear and concise manner that is uniformly understood by society. In addition to being an integral part of the terminological field of economics, AC terms are a special layer that reflects certain lexical and morphological as well as lexical-semantic features.

\section{References:}

1.Arnold, Dieter (2005). Temples of Ancient Egypt. I.B. Tauris. ISBN 978-945-5;.

2. Mikhailov B.P. Vitruvius and Hellas: Foundations of the ancient theory of architecture;

3. Robert Stuart (1854), Cyclopedia of architecture: historical, descriptive, typographical, decorative, theoretical and mechanical, alphabetically arranged, familiarly explained, and adapted to the comprehension of workmen, A. S. Barnes \& Co, p. 75;

4. H. Dadaboyev "Socio-political and socio-economic terminology in the Turkic-language written monuments of the XI-XIV centuries. " (1991),;

5. Dictionary of Architecture and Construction by Cyril M. Harris, pag.206;

6. Great Mosque of Kairouan (Qantara mediterranean heritage) Archived 2015-02-09;

7. A. Hourani A History of the Arab Peoples. London: Faber and Faber 1991;

8. Mahmud Kashgari, "Devonu lug'atit turk", Khurshid Davron. «Devonu lug'otit-turk»;ohanglari» 2020

9. Zahiriddin Muhammad Bobur "Boburnoma". Boburnoma, T., 1960;

10. Khurshid Davron, Sab'ai Sayyar »- the fourth epic of Navoi.2015; 